\title{
Estimative of the nutritional value of agroindustrial byproducts by using in vitro gas production technique
}

\section{Estimativa do valor nutricional de subprodutos agroindustriais pelo uso da técnica de produção de gás}

\author{
Elzânia Sales Pereira ${ }^{1 *}$; Ivone Yurika Mizubuti²; Edson Luis de Azambuja Ribeiro²; \\ José Neuman Miranda Neiva ${ }^{3}$; Patrícia Guimarães Pimentel ${ }^{4}$; \\ Labib Santos Duarte; ${ }^{5}$ Greicy Mitzi Bezerra Moreno ${ }^{6}$; Andréa Pereira Pinto ${ }^{7}$; \\ Marcus Roberto Goes Ferreira Costa $^{8}$; José Nery Rocha Júnior ${ }^{9}$
}

\begin{abstract}
The objective of this work was to determine the total carbohydrates fractions and to estimate the digestion rate of non-fibrous carbohydrates of agroindustrial byproducts by using the gas production technique. The agroindustrial byproducts evaluated were the following: cashew, passion fruit, pineapple, barbados cherry, annatto and melon, and each sample was incubated in quadruplicate. After mixing all contents thoroughly, the bottles were placed in an incubator at $39^{\circ} \mathrm{C}$, and connecting the lid of each bottle to a pressure sensitive switch, a solenoid valve and a vent stem connector. Gas pressure measurements were made at $0,3,6,12,15,18,22,26,30,34,40,48,60,72,96$ e 120 hours post-inoculation. Blanks and a standard were included to enable adjustments in variation among readings. There was a high variation in nutritional composition of agroindustry byproducts, that cashew and annato presented the highest protein contents (159.3 and $135.3 \mathrm{~g} / \mathrm{kg}$ of dry matter, respectively). Mellon and cashew presented the lowest values of total gas production ( 9.60 and $12.85 \mathrm{~mL}$, respectively); and annato, pineapple and passion fruit presented highest gas volume (32.80; 28.16 and $22.54 \mathrm{~mL}$, respectively), being the greatest percentages of $\mathrm{B}_{2}$ fraction $(64.27 ; 81.25$ and $67.49 \%$, respectively). Among the byproducts, pineapple and annatto stand out for the highest contribution of fibrous carbohydrate for total gas production, being $\mathrm{B}_{2}$ the main energy source for microbial growth, which is degraded at a slower rate than non-fibrous carbohydrate.

Key words: Bicompartimental model, degradation kinetics, neutral detergent fiber, non-fibrous carbohydrate
\end{abstract}

\section{Resumo}

Os objetivos deste trabalho foram determinar as frações de carboidratos totais e estimar a taxa de digestão dos carboidratos não-fibrosos de subprodutos agroindustriais, utilizando a técnica de produção de gás. Os subprodutos agroindustriais avaliados foram: caju, maracujá, abacaxi, acerola, urucum e melão, sendo

\footnotetext{
${ }^{1}$ Prof $^{\mathrm{a}}$ Dr $^{\mathrm{a}}$ do Dept $^{\mathrm{o}}$ de Zootecnia, UFC, Av. Mister Hull, 2977, Fortaleza, CE, Brasil, Tel. +55.85.33669749 - Pesquisadora do CNPq. E-mail: elzania@hotmail.com

2 Profs. Drs. do Dept ${ }^{\circ}$ de Zootecnia, UEL, Londrina, PR. Pesquisadores do CNPq. E-mail: mizubuti@uel.br; elar@uel.br

${ }^{3}$ Prof. Dr. do Dept ${ }^{\circ}$ de Zootecnia, UFT, Campus de Araguaína, Araguaína, TO. Pesquisador do CNPq. E-mail: araguaia@uft.edu.br

4 Prof $^{\mathrm{a}}$ Dr $^{\mathrm{a}}$ do Dept ${ }^{\mathrm{o}}$ de Zootecnia, UFC, Fortaleza, CE. E-mail: pgpimentel@hotmail.com

${ }^{5}$ Profa MSc. do Instituto Centec/FATEC Sertão Central, Quixeramobim, CE. E-mail: labib_duarte@yahoo.com.br*

${ }^{6}$ Prof $^{\mathrm{a}} \mathrm{Dr}^{\mathrm{a}}$ do Dept ${ }^{\mathrm{o}}$ de Zootecnia, UFAL, Arapiraca, AL. E-mail: greicymitzimoreno@yahoo.com.br

Prof ${ }^{a}$ Dr $^{\mathrm{a}}$ do Dept $^{\mathrm{o}}$ de Zootecnia, UFC, Fortaleza, CE. E-mail: deiapp@hotmail.com

8 Prof. Dr. do Ensino Básico, Técnico e Tecnológico do IFCE (Campus Crateús), Crateús, CE. E-mail: mr.goes@gmail.com

9 Zootecnista. Bolsista de Apoio Técnico/FUNCAP, Dept ${ }^{\circ}$ de Zootecnia, UFC, Fortaleza, CE. E-mail: junior.nery@hotmail.com

* Author for correspondence
} 
cada amostra incubada em quadriplicata. Após mistura minuciosa de todos os conteúdos, as garrafas foram colocadas em estufa a $39^{\circ} \mathrm{C}$ e foram conectadas a um interruptor sensível à pressão, com uma válvula solenóide e uma haste de ventilação. As medições de pressão do gás foram feitas a $0,3,6,12$, $15,18,22,26,30,34,40,48,60,72,96$ e 120 horas após a incubação. Branco e padrão foram incluídos para permitir ajustes na variação entre as leituras. Houve grande variação na composição nutricional dos subprodutos agroindustriais, sendo que caju e urucum apresentaram os maiores teores de proteína $(159,3$ e $135,3 \mathrm{~g} / \mathrm{kg}$ de matéria seca, respectivamente). Melão e caju apresentaram os menores valores de produção total de gás $(9,60$ e 12,85 mL, respectivamente); e urucum, abacaxi e maracujá apresentaram maiores volumes $(32,80 ; 28,16$ e 22,54 mL, respectivamente), sendo os maiores percentuais da fração $\mathrm{B}_{2}(64,27 ; 81,25$ e $67,49 \%$, respectivamente). Entre os subprodutos agroindustriais, abacaxi e urucum destacaram-se pela maior contribuição dos carboidratos fibrosos para produção de gás total, sendo a fração $\mathrm{B}_{2}$ a principal fonte de energia para o crescimento microbiano, que é degradada em um ritmo mais lento do que os carboidratos não-fibrosos.

Palavras-chave: Carboidratos não-fibrosos, cinética da degradação, fibra em detergente neutro, modelo bicompartimental

\section{Introduction}

Agroindustry byproducts of Brazilian northeast fruit play a major role as feeds for ruminants in arid and semiarid regions, particularly during the dry season when poor quality forage and crop residues are common (AHN et al., 1989; KIBONT; ØRSKOV, 1993). Among the fruits from the Northeast, the cashew (Anacardium occidentale) is of great importance, being cultivated in large areas and a processing industry well developed and disseminated in the region. Furthermore, the passion fruit (Passiflora edulis), which is a fruit from Central America, generates in its processing byproducts with plenty of bark, rich in pectin and minerals and feasible for being used in animal feeding.

Another byproduct of importance in the agricultural northeast is the pineapple (Ananas comosus L. Merr), which is a species originating in tropical America. Brazil is a major center of this species diversity. In various forms of consumption of fruit, a large amount of residue is generated, which because of lack of information, is no longer used in ruminant feeding. Barbados cherry (Malpighia emarginata) has a great production capacity in the Northeast and in their processing to obtain juices, jams, jellies and isolation of ascorbic acid, a large amount of residue is generated, which, when dried, can be incorporated into animal feeding.
Annatto (Bixa orellana L.) is a plant native of the tropical forests, whose main use is to obtain natural dyes, which are commonly used in the textile industry in the world. In Brazil, around 2.500t of annatto's byproduct are obtained annually after the extraction of bixin (dye), mainly in the Northeast, however, about $97 \%$ of the residue generated is not used (RÊGO et al., 2010). Another fruit in expansion in the Northeast is melon, belonging to the family Curcubitaceae, genus Cucumis, specie Cucumis melo. Although agroindustry byproducts can be alternatives for ruminant feeding, information in regard their nutritional value is needed.

Production and digestibility studies are vital to understanding of ruminant nutrition and feeding practices, but they require considerable resources in terms of labour, feed, animals and time. Degradation of forages in the rumen is a complex process, involving interactions among microorganisms (bacteria, protozoa, fungi) and between the microbial population and the host (CZERKAWSKI, 1986). While the in situ methodology (e.g., ØRSKOV; HOVELL; MOULD, 1980) has been widely used, the requirement for surgically modified animals raises ethical and moral issues. In addition, the high associated costs, limited analytical capacity and inability to evaluate many types of feeds tends to render this technique as being unattractive. A consequence has been the increased use of in vitro methodologies. 
Amongst those there are the gas production (GP) techniques which are used in many laboratories to study fermentation kinetics of ruminant feeds. In vitro cumulative gas production techniques were developed to predict fermentation of ruminant feedstuffs, which are incubated with buffered rumen fluid and the gas produced is measured as an indirect indicator of fermentation kinetics. When a feedstuff is incubated with buffered rumen fluid, the degraded fractions may either be fermented to produce gas and fermentation acids, or be incorporated into microbial biomass. When combined with measures of degradation, gas production techniques provide a measure of the proportion of feed that is fermented as opposed to that which is partitioned to microbial growth.

This study was carried out to determine the chemical composition and degradation kinetics of dry matter and neutral detergent fiber of agroindustrial byproducts of Brazilian fruit by gas cumulative technique.

\section{Material and methods}

\section{Feeds used as substrates}

The agroindustrial byproducts from the extraction of juices and pulps of cashew (Anacardium occidentale), pineapple (Ananas comosus L. Merr), passion fruit (Passiflora edulis), barbados cherry (Malpighia emarginata), annatto (Bixa orellana L.) and melon (Cucumis melo), were dehydrated in full sun on cemented area and sent to the Laboratory of Animal Nutrition (LANA) in the Department of Animal Science, Federal University of Ceara. All dried samples were ground through a $1 \mathrm{~mm}$ screen.

\section{Chemical composition and standard procedures}

Dry matter (DM, method ID 930.15), ash (method ID 924.05), ether extract (method ID 920.39), and crude protein (method ID 984.13) contents were determined by procedures of AOAC (1990). Neutral detergent fiber (NDF), acid detergent fiber (ADF), lignin (LIG), neutral detergent insoluble protein (NDIP) and acid (ADIP) were determined by using methods described by Van Soest, Robertson and Lewis (1991). Sodium sulphite and amylase were added to the solution for NDF determination. To analyze the neutral detergent fiber (NDF), the samples were treated with thermo-stable alpha amylase using sodium sulfite, corrected for residual ash (MERTENS, 2002) and for residual nitrogenous compounds (LICITRA; HERNANDES; VAN SOEST, 1996).

Total carbohydrates (TC) were determined by the following expression $\mathrm{TC}=100-(\% \mathrm{CP}+$ $\% \mathrm{EE}+\% \mathrm{MM}$; SNIFFEN et al., 1992), non-fibrous carbohydrates (NFC) were calculated from the equation adapted from Weiss (1999): $\mathrm{NFC}=100-$ $(\% \mathrm{CP}+\% \mathrm{EE}+\%$ NDFap $+\%$ ash $)$ where, NDFap is equivalent to the cell wall corrected for ash and protein.

\section{Animal donor and inocula}

Rumen liquor was obtained from one dairy cow (approximate $600 \mathrm{~kg}$ live weight), fitted with a rumen cannula and fed the same diet consisting of $600 \mathrm{~g} / \mathrm{kg}$ of grass hay and $400 \mathrm{~g} / \mathrm{kg}$ of concentrate (based on ground corn and soybean meal) on DM basis. The amount of ration provided to the animal was $12.5 \mathrm{~kg}$ of DM/day supplied in two equal meals. Rumen fluid was collected before the morning feeding and filtered through four layers of cheese cloth. The rumen solid phase was collected from the rumen dorsal sac through the cannula by hand and squeezed. The liquid phase was collected from the ventral sac using a stainless steel probe $(2.5$ $\mathrm{mm}$ screen) attached to a large capacity syringe. Fluids and solids were placed separately in prewarmed $\left(39^{\circ} \mathrm{C}\right)$ flasks and transported immediately to the laboratory. Equal volumes of solid and liquid phases of rumen fluid from each specie were mixed in a blender for approximately 10 seconds. After mixing, rumen fluid was squeezed through a $35 \mu \mathrm{m}$ 
nylon filter and kept in a water bath at $39^{\circ} \mathrm{C}$ with $\mathrm{CO}_{2}$ saturation until inoculation.

\section{In vitro technique}

Cumulative gas production (GP) profiles were generated by using methodology of Theodorou et al. (1994) as modified by Mauricio et al. (1999) with a pressure transducer and data logger (PDL200, LANA/CENA-USP, Piracicaba/SP, Brazil). In all assays, $1 \mathrm{~g}$ of sample was incubated in $160 \mathrm{~mL}$ serum bottles with $10 \mathrm{~mL}$ of inoculum and $90 \mathrm{~mL}$ of buffer solution. The culture medium contained buffer and mineral solutions and was prepared anaerobically (DAVIES et al., 2000). Bottles were tightly sealed with lids and warmed up to $39^{\circ} \mathrm{C}$ before inoculation with $10 \mathrm{~mL}$ of fresh filtered rumen fluid using disposable syringes. Bottles containing no substrate were included as blank to correct for organic matter (OM) disappearance, and gas and volatile fatty acid (VFA) production.

Each feed sample was incubated in quadruplicate. After mixing all contents thoroughly, the bottles were placed in an incubator at $39^{\circ} \mathrm{C}$, and the lid of each bottle was connected to a pressure sensitive switch, a solenoid valve and a vent stem connector. With this device, gas accumulating in the headspace of the bottles was released automatically when a pre-determined pressure was reached, thereby returning the pressure to atmospheric value. Gas pressure measurements were made at $0,3,6,12,15$, $18,22,26,30,34,40,48,60,72,96$ e 120 h postinoculation. Blanks and a standard were included to enable adjustments in variation among runs. Blanks were used for each inoculum to measure the fraction of total gas production due to substrate in inocula. These values were subtracted from the total to obtain net GP (GP due to substrate fermentation). A feed standard (a Tifton 85 hay sample) was used to determine the variations among the readings.
The kinetic parameters of gas production were evaluated according the bicompartmental model of Schofield, Pitt and Pell (1994):

$$
V=V f_{1} /\left(1+\exp ^{(2-4 \times C 1 \times(T-L)}\right)+V f_{2} /\left(1+\exp ^{(2-4 \times C 2(T-L)}\right)
$$

where: $V f_{1}$ is the maximum gas volume fraction of NFC (non fibrous carbohydrates);

C1 corresponds to the degradation rate $(\mathrm{mL} / \mathrm{h})$ of this same fraction (NFC);

$V f_{2}$ corresponds to the maximum gas volume fraction of CF (fibrous carbohydrates);

C2 represents the degradation rate of $\mathrm{CF}(\mathrm{mL} / \mathrm{h}) ; \mathrm{T}$ and $\mathrm{L}$ refers to incubation times (hours) and latency (hours), respectively.

The rates of ruminal degradation of NFC and NDF were estimated as $\mathrm{mm} / \mathrm{Vf}$, where $\mathrm{mm}$ is equivalent to the maximum rate of gas production. The kinetic parameters relative to the fraction of CNF were estimated from the cumulative gas production up to 12 hours of incubation, or until asymptote was established (STEFANON; PELL; SCHOFIELD, 1996; DOANE; PELL; SCHOFIELD, 1997; 1998).

\section{Statistical analyses}

To make the adjustments, the iterative Gauss Newton algorithm was used by using the program SAEG (System Analysis and Genetic Statistics) of Federal University of Viçosa, Brazil, (SAEG, 2007), adopting $\alpha=0.05$.

\section{Results and Discussion}

There was a high variation in nutritional composition of agroindustry byproducts (Table 1). Cashew and annato presented the highest protein contents (159.3 and $135.3 \mathrm{~g} / \mathrm{kg} \mathrm{DM}$, respectively), being annato the one that presented the lowest ADIP value $(19.3 \mathrm{~g} / \mathrm{kg} \mathrm{DM})$, which can indicate a greater 
availability of amino acids in the duodenum. The NDFap of the byproducts presented values of 510.0; 535.8; 509.1; 618.4; 372.8 and $669.0 \mathrm{~g} / \mathrm{kg}$ DM for cashew, passion fruit, pineapple, barbados cherry, annatto and melon, respectively. Availability of this fraction in the rumen is associated to the digestion rate in this site. Feeds with high values of NDF, as melon $(730.0 \mathrm{~g} / \mathrm{kg} \mathrm{DM})$, may provide energy at lower rate in the rumen and could affect negatively the microbial growth and animal performance. This is explained by indigestible fraction of NDF, which limits intake.

Table 1. Chemical composition of the Brazilian Northeast byproducts.

\begin{tabular}{|c|c|c|c|c|c|c|}
\hline \multirow[b]{2}{*}{ Nutrients } & \multicolumn{6}{|c|}{ Byproducts } \\
\hline & Cashew & Passion Fruit & Pineapple & $\begin{array}{r}\text { Barbados } \\
\text { cherry }\end{array}$ & Annato & Melon \\
\hline $\mathrm{DM}^{1}$ & 963.2 & 973.1 & 976.2 & 972.5 & 952.6 & 975.3 \\
\hline Ash & 36.2 & 132.7 & 107.0 & 60.8 & 63.2 & 68.5 \\
\hline $\mathrm{OM}^{1}$ & 964.0 & 867.0 & 893.0 & 939.0 & 937.0 & 932.0 \\
\hline $\mathrm{EE}^{1}$ & 15.0 & 4.0 & 6.0 & 9.0 & 21.0 & 8.0 \\
\hline $\mathrm{CP}^{1}$ & 159.3 & 97.0 & 78.4 & 90.6 & 135.3 & 87.5 \\
\hline $\mathrm{NDF}^{1}$ & 644.0 & 634.0 & 603.0 & 706.0 & 451.0 & 730.0 \\
\hline NDFap $^{1}$ & 510.0 & 535.8 & 509.1 & 618.4 & 372.8 & 669.0 \\
\hline $\mathrm{ADF}^{1}$ & 437.6 & 540.3 & 328.6 & 599.2 & 201.8 & 625.8 \\
\hline $\mathrm{LIG}^{2}$ & 269.3 & 110.8 & 98.4 & 294.2 & 152.2 & 334.6 \\
\hline $\mathrm{NFC}^{1}$ & 279.5 & 230.5 & 299.5 & 221.2 & 407.7 & 167.2 \\
\hline $\mathrm{TC}^{1}$ & 789.5 & 766.3 & 808.6 & 839.6 & 780.5 & 836.0 \\
\hline NDIP $^{1}$ & 108.5 & 44.6 & 43.6 & 54.5 & 42.8 & 44.8 \\
\hline $\mathrm{ADIP}^{1}$ & 44.4 & 29.9 & 20.4 & 39.7 & 19.3 & 32.7 \\
\hline
\end{tabular}

${ }^{1} \mathrm{~g} / \mathrm{kg} \mathrm{DM}$

${ }^{2} \mathrm{~g} / \mathrm{kg}$ NDF

Source: Elaboration of the authors.

Cashew, pineapple and annato presented the highest values of non-fibrous carbohydrates (NFC) (279.5; 299.5 and $407.7 \mathrm{~g} / \mathrm{kg} \mathrm{DM}$, respectively). Non-fibrous carbohydrates are important chemical constituents, because they represent sources of fast available energy for ruminal microorganisms, being this fraction the one which supports the initial microbial growth. Regarding to the inverse relationship between NDF content and intake, when ingestion is limited by ruminal repletion (MERTENS, 1987; MERTENS, 1994), it can be inferred that feeds with higher amount of NFC would allow higher intake. Therefore, the increase in NFC content theoretically would increase TDN content. Non-fibrous carbohydrates present almost complete nutritional availability for ruminants (VAN SOEST, 1967; MERTENS, 1996), but they increase the requirement in rumen degraded protein to meet nitrogen requirement of microorganism, which ferment these carbohydrates.

Mellon and cashew presented the lowest values of total gas production $(9.60$ and $12.85 \mathrm{~mL}$, respectively; Table 2), and this values may be due to the increment of lignin concentration (334.6 and $269.3 \mathrm{~g} / \mathrm{kg} \mathrm{DM}$ ), which markedly limit microbial access (Table 1). Regadas Filho et al. (2011), studying the degradation kinetics of the NDF indigestible fraction of the same byproducts of this study, recorded values of 961.9 and $725.0 \mathrm{~g} / \mathrm{kg} \mathrm{DM}$ for melon and cashew, respectively. Therefore, care must be taken with the inclusion of such byproducts, because they may limit voluntary intake, especially when the main forage presented low nutritional value. 
Table 2. Total gas volume of dry matter, proportion of gases from non fiber carbohydrates $\left(V f_{1} \%\right)$ and $\mathrm{B}_{2}\left(V f_{2} \%\right)$ fraction and digestion rates $(C)$

\begin{tabular}{cccccccccc}
\hline Byproduct & $V f_{1}$ & \multicolumn{1}{c}{$V f_{2}$} & Total gas & $C 1$ & $C 2$ & $V f_{1} \%$ & $V f_{2} \%$ & $\mathrm{~L}$ & $\mathrm{R}^{2}$ \\
\hline Cashew & 1.90 & 10.95 & 12.85 & 10.00 & 0.02 & 14.78 & 85.21 & 1.93 & 99.30 \\
Passion Fruit & 7.33 & 15.21 & 22.54 & 9.8 & 0.05 & 32.51 & 67.49 & 0.92 & 98.72 \\
Melon & 7.28 & 2.32 & 9.60 & 3.58 & 0.01 & 75.84 & 24.16 & 0.74 & 99.57 \\
Annato & 11.72 & 21.08 & 32.80 & 0.37 & 0.03 & 35.73 & 64.27 & 0.16 & 97.81 \\
Pineapple & 5.28 & 22.88 & 28.16 & 9.99 & 0.03 & 18.75 & 81.25 & 0.90 & 99.33 \\
Barbados cherry & 7.63 & 5.55 & 13.18 & 2.78 & 0.03 & 57.89 & 42.11 & 0.70 & 98.62 \\
\hline
\end{tabular}

Source: Elaboration of the authors.

Regadas Filho et al. (2011) reported that almost all of the indigestibility of the fibrous fraction of the melon and barbados cherry was associated with the composition of the studied material, mainly made up by seed coat, rich in lignin. The cashew, for example, has low availability of potentially digestible NDF, probably related to the high concentrations of condensed tannins observed in this byproduct (AGOSTINI-COSTA et al., 2003), which bind to cell wall compounds, resulting in indigestible or unavailable complexes to bacterial enzymes.

Contribution of NDF and NFC for total gas production of agroindustrial byproducts can be seen in Figure 1. Agroindustrial byproducts of annato, pineapple and passion fruit presented greater volumes of gas $(32.80 ; 28.16$ and 22.54 $\mathrm{mL}$, respectively), being the greatest percentages of phases from $\mathrm{B}_{2}$ fraction $(64.27 ; 81.25$ and $67.49 \%$, respectively).

Figure 1. Gas production curves of agroindustrial byproducts.

\section{$\mathrm{mL}$ of gas $/ 100 \mathrm{mg} \mathrm{DM}$}

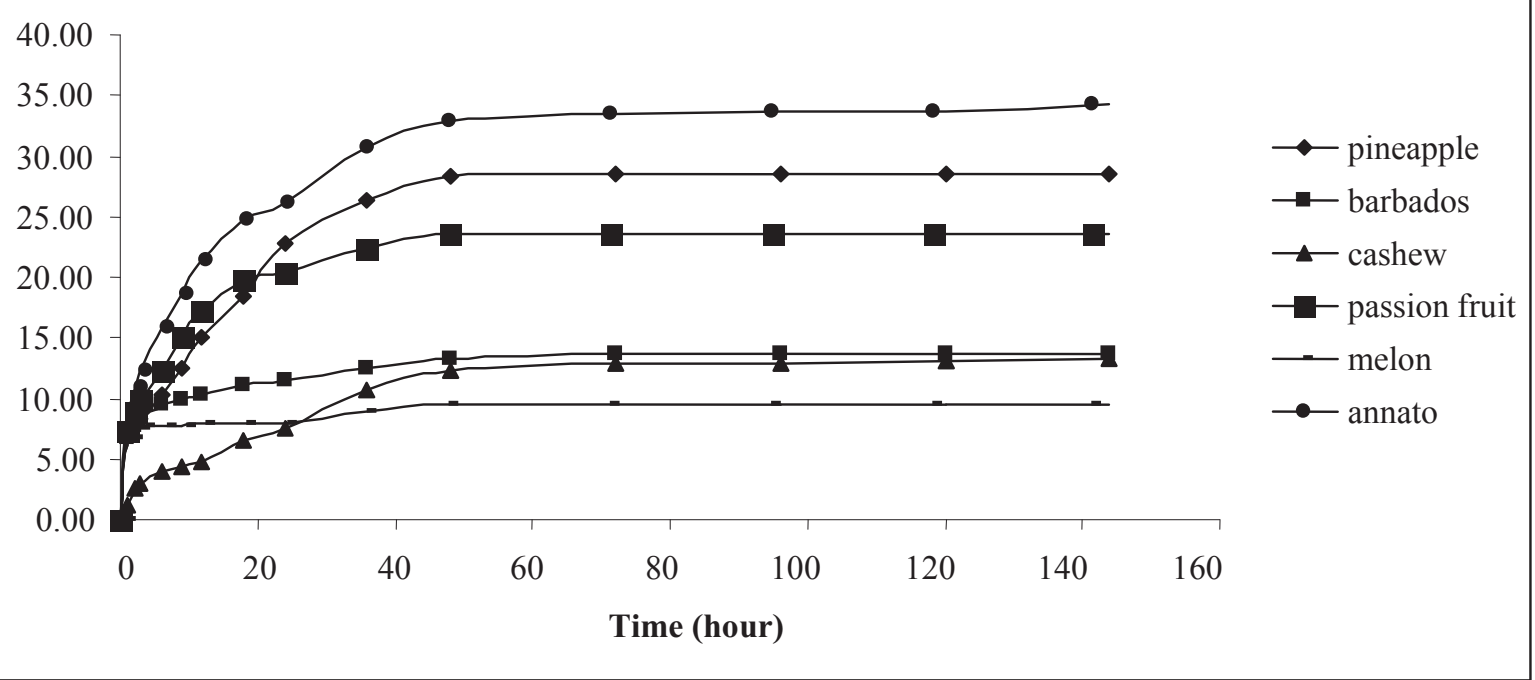

Source: Elaboration of the authors. 
According to Getachew et al. (2004), the amount of gas produced in feeds under incubation reflects the production of short chain fatty acids, which are the main energy source for ruminants. Gas production indirectly emerges from the reaction between buffer solution and acids resulting from fermentation and microbial degradation. It is expected that feeds which have great part of its carbohydrates in the starch form, present in the grains, will produce more propionate than acetate. According to Beuvink and Spoelstra (1992), production of propionate generates only 0.87 $\mathrm{mol} / \mathrm{mol}$ of VFA by means of indirect production and any gas directly, whereas acetate production generates 2 moles of $\mathrm{CO}_{2}$ per mol of glucose by direct production, and it indirectly produces $0.87 \mathrm{~mol} / \mathrm{mol}$ of VFA. Therefore, the cited authors suggested that comparison of feeds based only in gas cumulative production may lead to wrong conclusions on the energy value of the feeds inasmuch as molar proportion of the VFAs affects volume of gas produced per mol of fermented hexose.

The estimative of the digestion rate of NFC of the evaluated byproducts resulted in digestion rates which are related to microbial turnover and to changes on NDF digestion rate (CONE et al., 1996; CONE; VAN GELDER; DRIEHUIS, 1997; STEFANON; PELL; SCHOFIELD, 1996). The utilization of the gas volume produced between 12 and 24 hours after the incubation, to estimate the digestion rates, instead of 72 hours, is based on the fact that the NFC are rapidly fermented, resulting in gas cumulative production curves, whose asymptote is set within this period, indicating that this fraction was completely degraded (CABRAL et al., 2000). Digestion rates estimated for NFC are within the range from 10 to $40 \% / \mathrm{h}$ suggested by Sniffen et al. (1992) for carbohydrates $B_{1}$ fraction.

\section{Conclusion}

Among the byproducts, pineapple and annatto stand out for the greatest contribution of fibrous carbohydrate for total gas production, being $\mathrm{B}_{2}$ the main energy source for microbial growth, which is degraded at a slower rate than non-fibrous carbohydrate.

\section{References}

AGOSTINI-COSTA, T. S.; LIMA, A.; LIMA, M. V. Determinação de tanino em pedúnculo de caju: método da vanilina versus método do butanol ácido. Química Nova, São Paulo, v. 26, n. 5, p. 763-765, 2003.

AHN, J. H.; ROBERTSON, B. M.; ELLIOT, R.; GUTTERIDGE, C.; FORD, C. W. Quality assessment of tropical browse legumes: tannin content and protein degradation. Animal Feed Science and Technology, Amsterdam, v. 27, n. 1-2, p. 147-156, 1989.

ASSOCIATION OF OFFICIAL ANALYTICAL CHEMISTS - AOAC. Official methods of analysis. 15. ed. Virginia: Arlington, 1990. 1117 p.

BEUVINK, J. M. W.; SPOELSTRA, S. F. Interactions between substrate, fermentation end-products, buffering systems and gas production upon fermentation of different carbohydrates by mixed rumen microorganisms in vitro. Applied Microbiology and Biotechnology, New York, v. 37, n. 4, p. 505-509, 1992.

CABRAL, L. S.; VALADARES FILHO, S. C.; MALAFAIA, P. A. M.; LANA, R. P.; SILVA, J. F. C.; VIEIRA, R. A. M.; PEREIRA, E. S. Frações de carboidratos de alimentos volumosos e suas taxas de degradação estimadas pela técnica de produção de gases. Revista Brasileira de Zootecnia, Viçosa, MG, v. 29, n. 6, p. 2087-2098, 2000. Suplemento 1.

CONE, J. W.; VAN GELDER, A. H.; DRIEHUIS, F. Description of gas production profiles with a threephasic model. Animal Feed Science and Technology, Amsterdam, v. 66, n. 1-4, p. 31-45, 1997.

CONE, J. W.; VAN GELDER, A. H.; VISSCHER, G. J. W.; OUDSHOORN, L. Influence of rumen fluid and substrate concentration on fermentation kinetics measured with a fully automated time related gas production apparatus. Animal Feed Science and Technology, Amsterdam, v. 61, p. 1-4, p. 113-128, 1996.

CZERKAWSKI, J. W. An introduction to rumen studies. Oxford, New York: Pergamon International Library. 236 p. 1986.

DAVIES, Z. S.; MASON, D.; BROOKS, A. E.; GRIFFITH, G. W.; MERRY, R. J.; THEODOROU, M. $\mathrm{K}$. An automated system for measuring gas production from forages inoculated with rumen fluid and its use in determining the effect of enzymes on grass silage. Animal Feed Science and Technology, Amsterdam, v. 83, n. 3-4, p. 205-221, 2000. 
DOANE, P. H.; PELL, A. N.; SCHOFIELD, P. Ensiling effects on the ethanol fractionation of forages using gas production. Journal of Animal Science, Madison, v. 76, n. 3, p. 888-895, 1998.

The effect of preservation method on the neutral detergent soluble fractions of forages. Journal of Animal Science, Madison, v. 75, n. 4, p. 1140-1148, 1997.

GETACHEW, G.; ROBINSON, P. H.; DEPETERS, E. J.; TAYLOR, S. J. Relationship between chemical composition, dry matter degradation and in vitro gas production of several ruminant feeds. Animal Feed Science and Technology, Amsterdam, v. 111, n. 1-4, p. 57-71, 2004.

KIBONT, A.; ØRSKOV, E. R. The use of degradation characteristics of browse plants to predict intake and digestibility by goats. Animal Production, v. 57, n. 2, p. 247-251, 1993.

LICITRA, G.; HERNANDES, T. M.; VAN SOEST, P. J. Standardization of procedures for nitrogen fractionation of ruminants feeds. Animal Feed Science and Technology, Amsterdam, v. 57, n. 4, p. 347-358, 1996.

MAURICIO, R. M.; MOULD, F. L.; DHANOA, M. S.; OWEN, E.; CHANNA, K. S.; THEODOROU, M. K. A semi-automated in vitro gas production technique for ruminant feedstuff evaluation. Animal Feed Science and Technology, Amsterdam, v. 79, n. 4, p. 321-330, 1999.

MERTENS, D. R. Gravimetric determination of amylasetreated neutral detergent fibre in feeds with refluxing beakers or crucibles: collaborative study. Journal of AOAC International, v. 85, p. 1217-1240, 2002.

Predicting intake and digestibility using mathematical models of ruminal function. Journal of Animal Science, Madison, v. 64, n. 5, p. 1548-1558, 1987.

Regulation of forage intake. In: FAHEY JR., G. C. (Ed.). Forage quality, evaluation, and utilization. Madison: American Society of Agronomy, 1994. p. 450493.

Using fiber and carbohydrate analyses to formulate dairy rations. In: INFORMATIONAL CONFERENCE WITH DAIRY AND FORAGES INDUSTRIES, 1996, Wisconsin. Proceedings... Wisconsin: 1996. p. 81-92.

ØRSKOV, E. R.; HOVELL, F. D.; MOULD, F. The use of the nylon bag technique for evaluation of feedstuffs. Tropical Animal Production, Merida, v. 5, n. 3, p. 19521, 1980.
REGADAS FILHO, J. G. L.; PEREIRA, E. S.; PIMENTEL, P. G.; OLIVEIRA, T. S.; COSTA, M. R. G. F.; MAIA, I. S. G. Degradation kinetics and assessment of the prediction equation of indigestible fraction of neutral detergent fiber from agroindustrial byproducts. Revista Brasileira de Zootecnia, Viçosa, MG, v. 40, n. 9, p. 1997-2004, 2011.

RÊGO, A. C.; CÂNDIDO, M. J. D.; PEREIRA, E. S.; FEITOSA, J. V.; RÊGO, M. M. T. Degradação de silagens de capim-elefante contendo subproduto do urucum. Revista Ciência Agronômica, Fortaleza, v. 41, n. 3, p. 482-489, 2010.

SAEG. SAEG: sistema para análises estatísticas, versão 9.1. Viçosa: UFV, 2007.

SCHOFIELD, P.; PITT, R. E.; PELL, A. N. Kinetics of fiber digestion from in vitro gas production. Journal Animal Science, Madison, v. 72, n. 11, p. 2980-2991, 1994.

SNIFFEN, C. J.; O'CONNOR, D. J.; VAN SOEST, P. J.; FOX, D. G.; RUSSELL, J. B. A net carbohydrate and protein system for evaluating cattle diets: carbohydrate and protein availability. Journal of Animal Science, Madison, v. 70, n. 11, p. 3562-3577, 1992.

STEFANON, B.; PELL, A. N.; SCHOFIELD, P. Effect of maturity on digestion kinetics of water-soluble and water insoluble fractions of alfafa and brome hay. Journal of Animal Science, Madison, v. 74, n. 5, p. 1104-1115, 1996.

THEODOROU, M. K.; WILLIAMS, B. A.; DHANOA, M. S.; MCALLAN, A. B.; FRANCE, J. A simple gas production method using a pressure transducer to determine the fermentation kinetics of ruminant feeds. Animal Feed Science and Technology, Amsterdam, v. 48, n. 3-4, p. 185-197, 1994.

VAN SOEST, P. J. Development of a comprehensive system of feeds analysis and its applications to forages. Journal of Animal Science, Madison, v. 26, n. 1, p. 119128, 1967.

VAN SOEST, P. J.; ROBERTSON, J. B.; LEWIS, B. A. Symposium: carbohydrate methodology, metabolism and nutritional implications in dairy cattle. Journal of Dairy Science, Madison, v. 74, n. 10, p. 3583-3597, 1991.

WEISS, W. P. Energy prediction equations for ruminant feeds. In: CORNELL NUTRITION CONFERENCE FOR FEED MANUFACTURERS, 61., 1999, Ithaca. Proceedings... Ithaca: Cornell University, 1999. p. 176. 